\title{
SWOT ANALYSIS OF HEALTH TOURISM IN TURKEY
}

\author{
TÜRKIYYE'DE SAĞLIK TURİMİ SWOT ANALIZZi
}

\author{
Menekşe KILIÇARSLAN ${ }^{1}$
}

\begin{abstract}
The healthcare sector plays an important role both in terms of function and contribution to the country's economy both in Turkey and in the World. Increasing service alternatives due to the technological improvement and recently emerged diseases, and the increase in the elder population brought competition and alternative treatment options. The ease of communication and transportation brought many factors that affect tourism in the field of healthcare. In the study, the healthcare in Turkey and in the world was examined, the types of healthcare tourism and the factors that triggered it were tried to be explained. In the world and in Turkey healthcare tourism policies, patient statistics from abroad, number of patients, public and private sector distributions of these numbers are summarized in the inventory of health tourism. The data in the world and Turkey will be analyzed, Swot analysis will be used to determine the situation for Healthcare tourism, which is of great importance in the world and in Turkey and the results will be given. These results have been aimed to create a point of view on the new and developing sector of research in the world and in Turkey.
\end{abstract}

Keywords: Health, Health Care, Health Tourism, Swot Analysis.

Öz

Sağlık sektörü hem Türkiye'de hem de dünyada ülke ekonomisine hem fonksiyon hem de katkı bakımından önemli bir rol oynamaktadır. Teknolojik gelişme ve yeni ortaya çıkan hastalıklar nedeniyle hizmet alternatiflerinin artması ve yaşlı nüfustaki artış rekabet ve alternatif tedavi seçenekleri getirmiştir. İletişim ve ulaşım kolaylığı, sağlık alanında turizmi etkileyen birçok faktör getirmiştir. Araştırmada, Türkiye'de ve dünyada sağlık hizmetleri incelenmiş, sağlık turizmi türleri ve tetikleyen faktörler açıklanmaya çalışılmıştır. Dünyada ve Türkiye'de sağlık turizmi politikaları, yurtdısından hasta istatistikleri, hasta sayısı, bu sayıların kamu ve özel sektör dağılımları sağlık turizmi envanterinde özetlenmiştir. Dünyadaki ve Türkiye'deki veriler analiz edilecek, dünyada ve Türkiye'de çok önemli olan Sağlık turizmi durumunu belirlemek için Swot analizi kullanılacak ve sonuçları verilecek. Bu sonuçların, dünyada ve Türkiye'de yeni ve gelişmekte olan araştırma sektörüne bir bakış açısı yaratması amaçlanmıştır.

Anahtar Kelimeler: Sağlık, Sağlık hizmeti, Sağlık turizmi, Swot Analiz

\footnotetext{
${ }^{1}$ Istanbul Aydin University, Health Management Department, meneksekilicarslan69@gmail.com.tr, Orcid:0000-0002-0580-8645
}

Makale Türü: Araştırma Makalesi - Geliş Tarihi:05/10/2018 - Kabul Tarihi: 27/05/2019 


\section{INTRODUCTION}

\subsection{Health Tourism}

Health tourism can be defined as the trip to another place of residence to benefit from the health and tourism facilities for at least 24 hours for the purpose of protecting health, developing and treating diseases (Kördeve, 2010).

Health tourism is organized trips outside the periphery for the protection, development and improvement of mental and physical well-being of people (Carrera \& Bridges, 2006).

\subsubsection{Classification of Health Tourism}

When we check the subbranches that are related to medical tourism, we see that they cover, advanced treatments (cardiovascular surgery, radiotherapy, cyberknife etc.), transplantation, infertility (IVF applications), aesthetic surgery, eye, teeth anddialysis treatments (Kaptanoğlu, 2017). Their service areas are health institutions and organizations and they are provided by health personnel and especially by doctors (totally physiciancentered service).

Thermal Tourism and SPA-Wellnes; Thermal and spa-wellness tourism is perhaps the most ancient type of health tourism that is known to man. People have gone to places where thermal water resources are available to find healing. According to the year 2006, 8 million people in Germany alone travelled domestic or abroad for treatment or spa-wellness purposes in thermal springs. In 2006, the number of health tourists coming from abroad to Turkey for thermal tourism is around 10 000. For Turkey, which has about 200 civilizations in 46 provinces with thermal resources, it is not possible to say that these figures are satisfactory, but it is also quite remarkable in terms of potential (WTO, 2010).

Thermal tourism and SPA-Wellnes related areas; Spa treatments that are offered in spa, health and wellness facilities are thalassotherapies, hydrotherapy, balneotherapy, peloidotherapy and climatotherapy. The service is provided by the assistant health staff and other staff (very little need of doctor).

Elderly and Disabled Tourists; Old age and handicapped tourism are a kind of health tourism especially for those people who have an age of 65 years and above, especially for those that require care in parallel with the increasing average age in the last 20-30 years. The increase in the proportion of the elderly population to the total population, especially in western European countries, is remarkable in terms of this tourism variety. In some countries, the proportion of the population over 65 years of age exceeds $25 \%$. This development brings along different health expenditures and different treatment processes for older people. In the advanced age tourism, sightseeing tours, rehabilitation services, various therapies, care for the elderly in care homes, special visits for the disabled and treatment for care are the sub topics of this health tourism type (Kılıçarslan, 2017).

\subsection{Health Tourism Situation in the World}

Since the mid 1990s, health tourism has become an alternative tourism type due to globalization and competition environment. Countries like India, Cuba, Costa Rica, Thailand, Singapore, Colombia and Malaysia are the most preferred countries for health tourism. For this reason, the main region of health tourism is Asia.

In order to compete with Singapore, Malaysia and Thailand, which are the countries entering the health tourism field later, other countries have lowered their prices below these countries and set up information stands on medical tourism alternatives at airports (Connell, 2006). 
Thailand became prominent in medical tourism as a result of successes in gender exchange operations in the 1970s, and in the following years, it increased its effectiveness in the medical tourism market with cosmetic surgery (Connell, 2006). The "Bumrungrad Hospital", the largest investment in Thailand's medical tourism in 2000, is one of the top 10 medical tourism hospitals in the world. Since 2004, Thailand has started to implement a new medical tourism investment policy and aimed to position itself as the medical tourism center of Asia. In the World Bank easy investment index, Thailand became the sixth country in the world and the second country in Asia. For those seeking to invest in medical tourism, Thailand has included national taxation exemptions, facilities for medical supplies and the reduction of procedures (Dinçer, 2016).

After the Asian economic crisis in 1998, Malaysia started to search for ways to recover from the crisis, and in this context, it made a breakthrough in moving the potential of medical tourism. Most of the tourists who prefer medical tourism services in Malaysia constitute travelers from countries in the Far East region. In this context, it is important for Malaysia to establish an attractive position for medical tourists who are likely to travel the medical tourism network in remote areas in policies and plans to be developed in the future. One of Malaysia's greatest advantages in this area is that it offers surgical operations with short waiting times. Apart from this, it has been effective in having a preferred position in the medical tourism market by presenting medical activities with alternative health activities and tourism products which are long lasting. It is a Muslim country that Malaysia can use as a competitive advantage in medical tourism and can not sufficiently evaluate itself. It is thought that this advantage can be used more advantageously than non-Muslim competitors at the point where they can use it adequately (Dinçer, 2016).

It is the quality of health care services in European countries. However, in Europe, expensive health care and long wait times force patients to seek health care from other countries. Especially in areas such as hip, heart, lung operations and infertility treatment, health services are being obtained from other countries (Gülen \& Demirci, 2012).

The main countries attracting tourists in health tourism around the world are; Panama, Brazil, Costa Rica, Hungary, Malaysia, India, Jordan, Thailand, Singapore and South Korea (Barca, Akdeve \& Gedik, 2013).

Undeveloped countries; most of the countries that send tourists are Sudan, Somalia, Afghanistan, Libya and undeveloped countries because of the lack of health service provision and the number of staff.

Asian countries; most of the countries that send tourists are Asian countries like Pakistan, Iraq and Syria because of the lack of health service provision and the number of personnel.

American and European countries; American and European countries send tourists because of the high cost of health care and the long wait times.

Countries with a lot of elderly population; there are countries that send tourists due to inadequate number of staff, large number of elderly population and high cost of care.

\subsection{Health Tourism Status in Turkey}

Medical tourism is a new concept and a new field of study for Turkey as well as being new all over the world. Despite having a short history, medical tourism, which attracts attention of all stakeholders of the sector, presents new opportunities in front of Turkey. Without overlooking that these opportunities can be evaluated and earned in the country's 
economy, it can be considered an important step to keep this academy alive, as well as publicprivate sector interest (Aktürk, 2016).

In medical tourism, dental interventional operations which should be emphasized as aesthetic operations, small surgical interventions and great potential, especially eye, refer to sub-topics of medical tourism, oncology, orthopedics, cardiology and neurosurgery. It is necessary to emphasize that all these branches are physician-focused.

\subsubsection{Foreign Health Services Provided in Turkey}

Health services provided to foreigners for a long time in Turkey; Health services are offered in emergency routine treatments for foreigners retired as the consulate staff and placed in cities like Alanya and Marmaris.

\subsubsection{Distribution of Health Tourists to Turkey by Country}

1. Countries with a large population of Turks due to various reasons (Germany, Holland, France etc.)

2. Developing countries (Balkan countries, Turkic Republics in Central Asia) suffering from service difficulties due to infrastructure and physician inadequacy,

3. Countries where the health services are expensive and the patients who require services not covered by insurance (USA, UK, Germany)

4. Countries with long waiting lists due to inadequacy of supply demand balance (UK, Netherlands and Canada)

5. Countries sending a certain number of free patients to Turkey in the framework of bilateral agreements (Afghanistan, Yemen Sudan etc.).

International types of patients have declined in 2016 compared to the previous year. Medical tourism decreased by around $12 \%$ while tourist health decreased by about $5 \%$ (Figure 1).

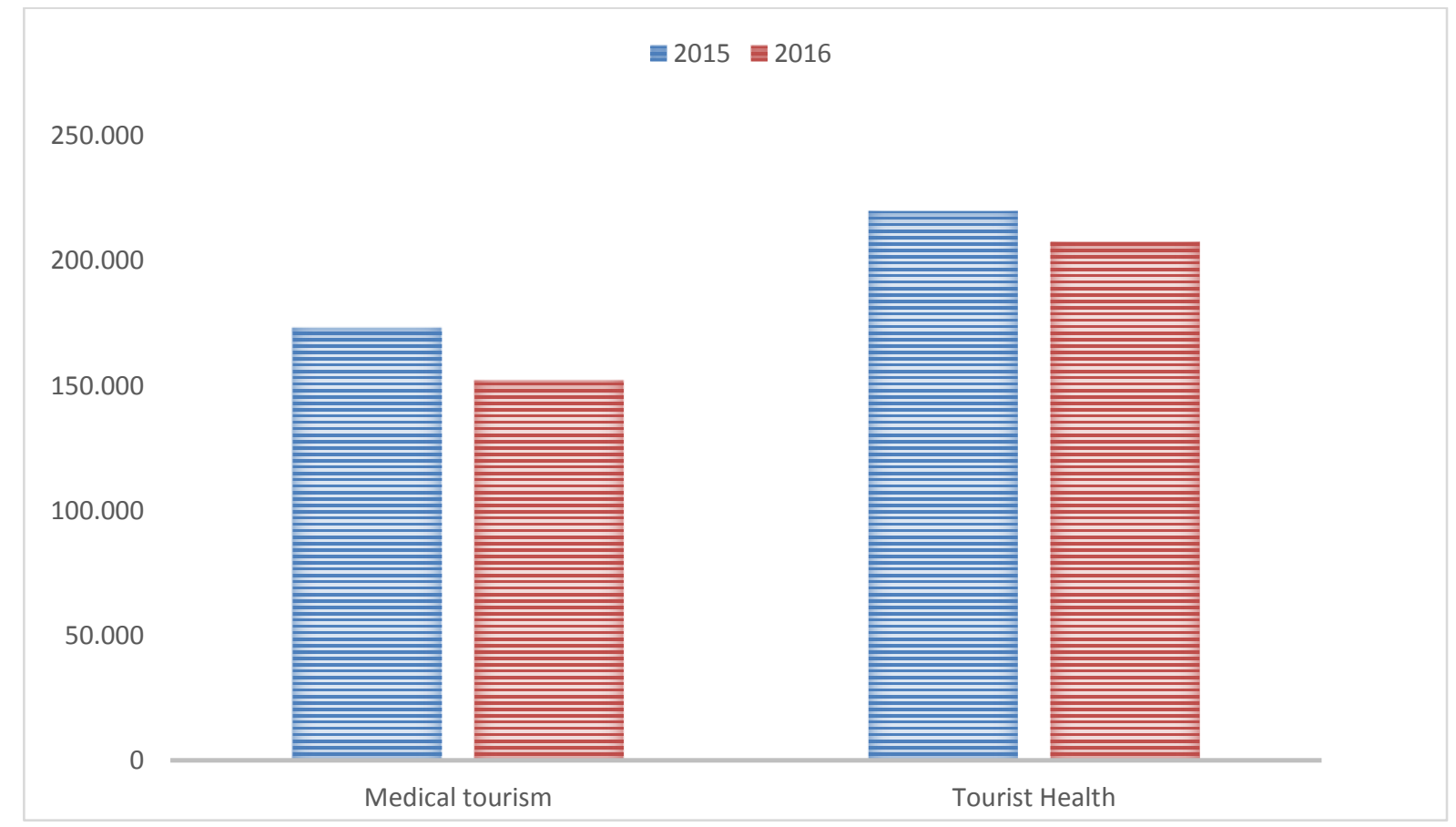

Resource; Turkey International Patient Report 2015-2016

Figure 1. International Patients Coming Kinds, 2015-2016 
Within the scope of medical tourism to our country, the most patients come from Libya in 2015 and 2016, the most in Germany in 2015 and 2016 within the scope of tourist health came from patients (Table 1-2). While the number of international patients from Libya in medical tourism declined by about $65 \%$, the number of international patients from Germany decreased by about $26 \%$ in the area of tourist health. In $2015,52 \%$ of the international patients from the top 10 countries came to tourism health and $48 \%$ came to medical tourism. In 2016, it is seen that $60 \%$ of the people from the top 10 countries are in the tourist health and $40 \%$ are in the scope of medical tourism (Y1ldırım, 2017).

Table 1: Top 10 Countries that patients come from, 2015-2016

\begin{tabular}{|l|r|r|r|l|r|r|r|}
\hline \multicolumn{4}{|c|}{ 2015 YEAR } & \multicolumn{4}{c|}{ 2016 YEAR } \\
\hline Country & $\begin{array}{l}\text { Medical } \\
\text { Tourism }\end{array}$ & $\begin{array}{l}\text { Tourist } \\
\text { Health }\end{array}$ & Total & Country & $\begin{array}{l}\text { Medical } \\
\text { Tourism }\end{array}$ & $\begin{array}{l}\text { Tourist } \\
\text { Health }\end{array}$ & Total \\
\hline Libya & 37,470 & 7,648 & 45,118 & Germany & 4,863 & 16,896 & 21,759 \\
\hline Iraq & 18,993 & 13,632 & 32,625 & Azerbaijan & 12,318 & 8,496 & 20,814 \\
\hline Germany & 7,261 & 23,105 & 30,366 & Iraq & 11,026 & 7,973 & 18,999 \\
\hline Azerbaijan & 17,668 & 10,944 & 28,612 & Libya & 12,855 & 6,140 & 18,995 \\
\hline Russia & 4350 & 11,502 & 15,852 & Syria & 1,919 & 12,589 & 14,508 \\
\hline Syria & 2,419 & 12,587 & 15,006 & Turkmenistan & 2,684 & 5,944 & 8,628 \\
\hline Turkmenistan & 4,616 & 7,941 & 12,107 & England & 1,266 & 6,864 & 8,130 \\
\hline England & 1,543 & 8,128 & 9,671 & Holland & 1,385 & 5,711 & 7,096 \\
\hline Afghanistan & 3,169 & 6,094 & 9,263 & Russia & 2,371 & 4,387 & 6,758 \\
\hline Holland & 1,663 & 6,268 & 7,931 & S.Arabia & 2,179 & 3,568 & 5,747 \\
\hline
\end{tabular}

Resource; Turkey International Patient Report 2015-2016

Table 2: Preferences of Top 3 Countries that international patient comes from, 2015- 2016

\begin{tabular}{|c|c|c|c|c|c|c|c|c|c|c|c|}
\hline \multicolumn{4}{|c|}{ Year 2015 } & \multicolumn{5}{c|}{ Year 2016 } \\
\hline \multicolumn{2}{|c|}{ Libya } & \multicolumn{2}{|c|}{ Iraq } & \multicolumn{2}{c|}{ Germany } & \multicolumn{2}{c|}{ Germany } & \multicolumn{2}{c|}{ Azerbaijan } & \multicolumn{3}{c|}{ Iraq } \\
\hline İstanbul & 33.565 & İstanbul & 17.323 & Antalya & 16.427 & Antalya & 10.117 & İstanbul & 11.587 & İstanbul & 9.110 \\
\hline İzmir & 6.438 & Ankara & 8.021 & İstanbul & 7.709 & İstanbul & 5.716 & Ankara & 4.510 & Ankara & 5.867 \\
\hline Ankara & 4.581 & Diyarbakır & 2.422 & Muğla & 1.396 & Ankara & 1.201 & Erzurum & 1.375 & Eskişehir & 1.446 \\
\hline
\end{tabular}

Resource; Turkey International Patient Report 2015-2016

The total number of international patients coming to Libya from Istanbul, Izmir and Ankara for health services in 2015 is 44,584 . Approximately $75 \%$ of these patients preferred to receive health services in the province of Istanbul. The total number of international patients who came to Iraq from Iraq, Ankara and Diyarbakir to receive health services in 2015 is 27,766 . Approximately $62 \%$ of these patients preferred to receive health services in the province of Istanbul. The total number of international patients arriving from Iraq in 2016 to receive health services in Istanbul, Ankara and Eskişehir is 16,423. Approximately 55\% of these patients preferred to receive health services in the province of Istanbul. The total number of international patients coming from Germany to Antalya, Istanbul and Muğla to receive health services in 2015 is 25,532 . Approximately $59 \%$ of these patients preferred to receive health services in the province of Antalya. In 2016, the total number of international 
patients coming from Germany to Antalya, Istanbul and Ankara for health services is 17034 . Approximately $75 \%$ of these patients preferred to receive health services in the province of Istanbul. The total number of international patients coming to Azerbaijan from Istanbul, Ankara and Erzurum to receive health services in 2016 is 17,472. Approximately $66 \%$ of these patients preferred to receive health services in the province of Istanbul.

In 2015 and 2016, private health institutions and organizations are among the first in the distribution of international patients receiving health care services in our country (Figures 2-3, Figures 4-5). Although it is the first place in health tourism to include private health institutions and institutions, it can be stated that it is at a low level. This may be attributed to the decline in the number of medical tourists who prefer private health institutions and establishments and the desire to share the data of private health institutions and institutions based on various reasons (Yildirım, 2017).
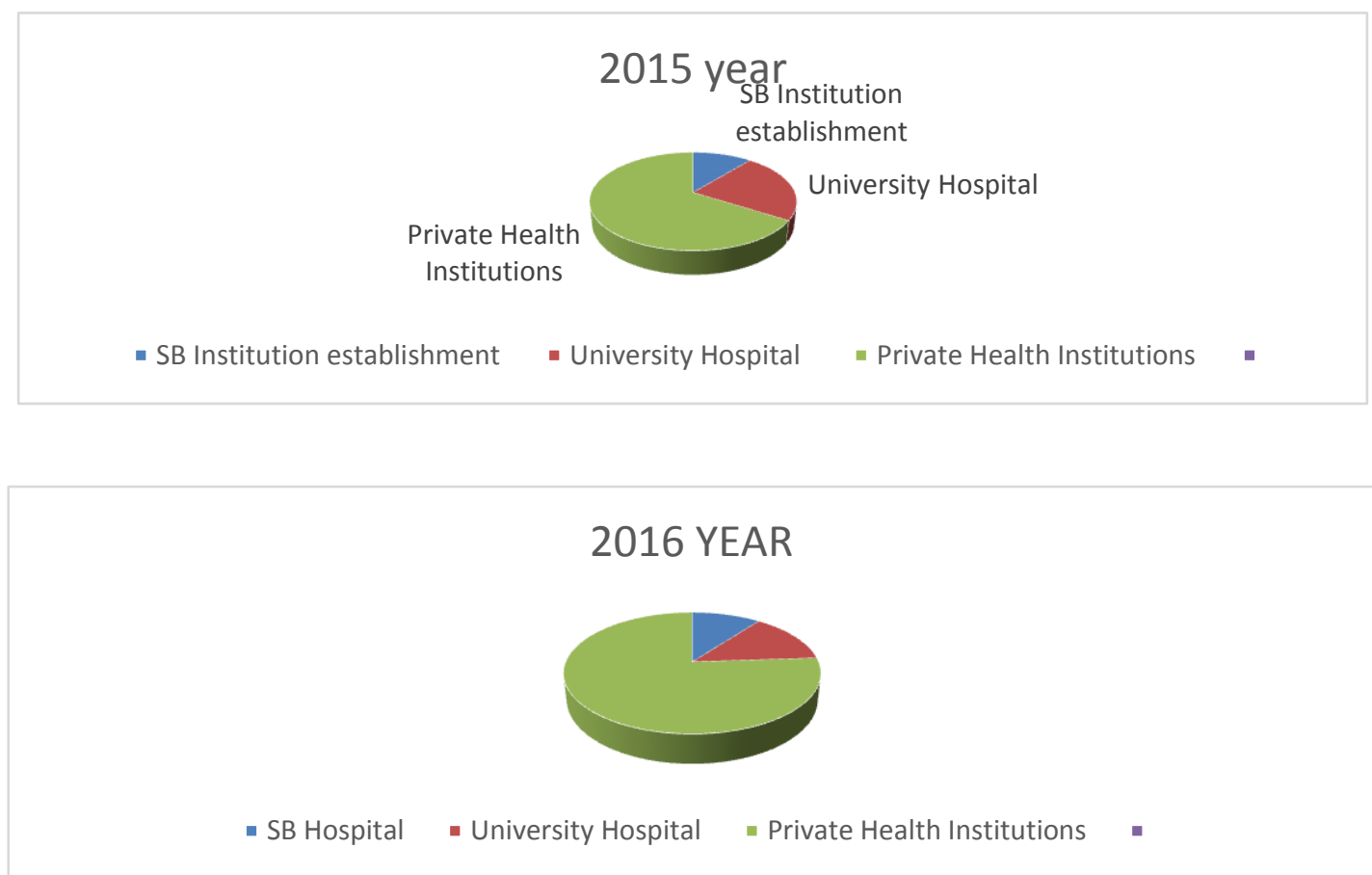

Resource; Turkey International Patient Report 2015-2016

Figures 2-3. Foreign Patients Distributions according to Institutions, 2015-2016 


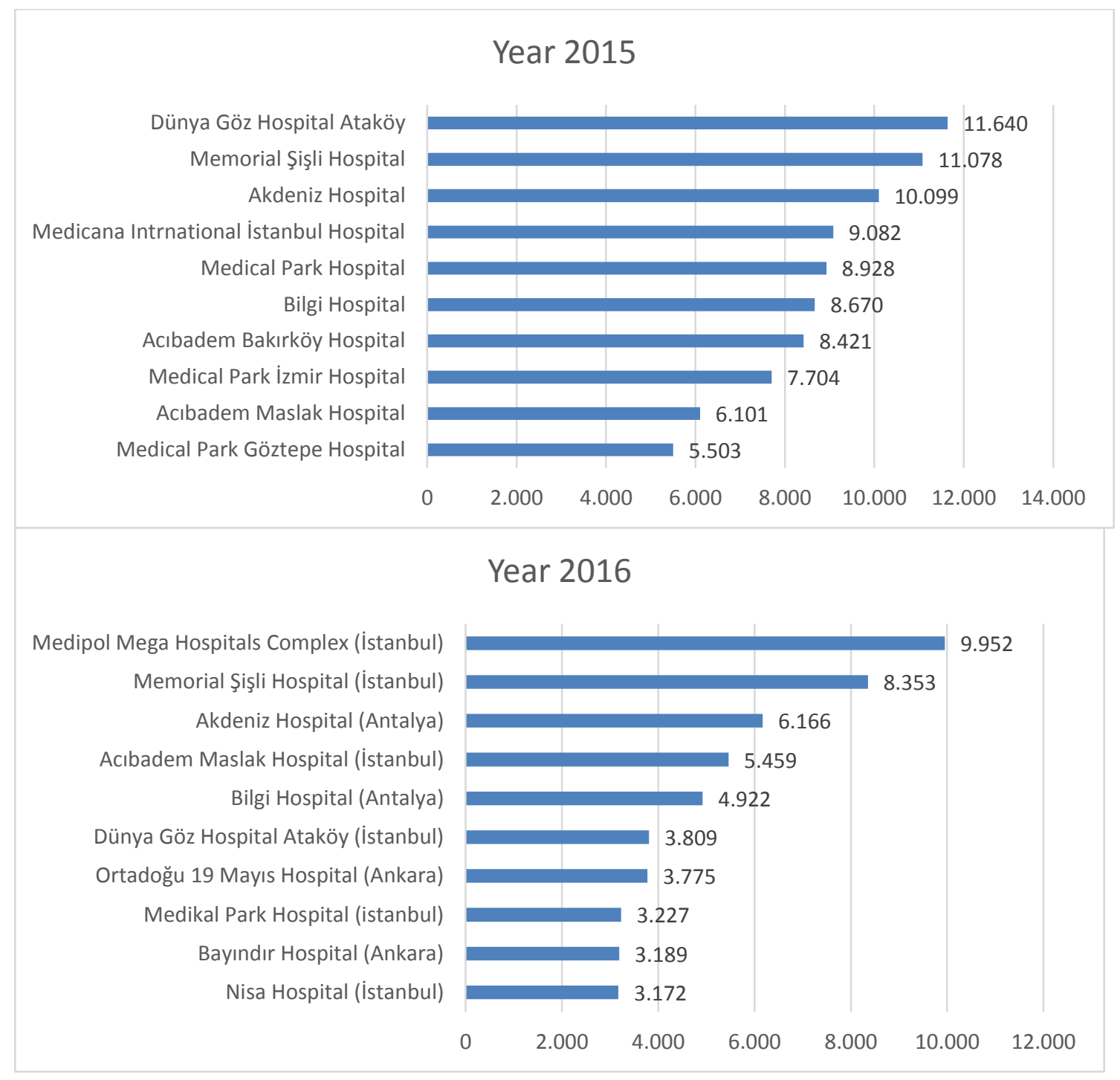

Resource; Turkey International Patient Report 2015-2016

Figures 4-5: International Patients Top 10 Preferences Private Hospitals, 2015-2016

When international arrivals from the top 10 private hospitals are examined in 2015, it is seen that they mostly come within the scope of medical tourism. $67 \%$ of the applications made to the top 10 hospitals with the highest number of international patients were within the scope of medical tourism and 33\% were within the scope of the tourist health. In 2016, international patients are predominantly in the context of tourist health. $55 \%$ of the applications made to the first 10 hospitals that attract the most international patients were within the scope of the touristic health and $45 \%$ of them were within the scope of medical tourism (Table 3) (Yıldırım, 2017). 
Table 3: Most Preferred Private Hospitals Coming Kinds, 2015-2016

\begin{tabular}{|c|c|c|c|c|}
\hline \multirow{13}{*}{ 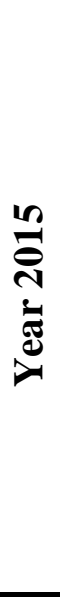 } & Hospital & Medical Tourism & Health of Tourist & Total \\
\hline & Dünya Göz Hospital Ataköy & 8.080 & 3.560 & 11.640 \\
\hline & Memorial Şişli Hospital & 10.836 & 242 & 11.078 \\
\hline & Akdeniz Hospital & 8 & 10.091 & 10.099 \\
\hline & Medicana Intrnational İstanbul Hospital & 4.966 & 4.116 & 9.082 \\
\hline & Medical Park Hospital & 5.630 & 3.298 & 8.928 \\
\hline & Bilgi Hospital & 8.238 & 432 & 8.670 \\
\hline & Acıbadem Bakırköy Hospital & 3.603 & 4.818 & 8.421 \\
\hline & Medical Park İzmir Hospital & 6.348 & 1.356 & 7.704 \\
\hline & Acibadem Maslak Hospital & 6.045 & 56 & 6.101 \\
\hline & Medical Park Göztepe Hospital & 4.439 & 1.064 & 5.503 \\
\hline & Total & 58.193 & 29.033 & 87.226 \\
\hline & Percentage & $67 \%$ & $33 \%$ & $100 \%$ \\
\hline \multirow{13}{*}{ 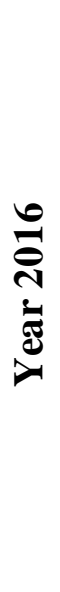 } & Hospital & Medical Tourism & Health of Tourist & Total \\
\hline & Medipol Mega Hospitals Complex (İstanbul) & 5.390 & 4.562 & 9.952 \\
\hline & Memorial Şişli Hospital (İstanbul) & 7.967 & 386 & 8.353 \\
\hline & Akdeniz Hospital (Antalya) & 1 & 6.165 & 6.166 \\
\hline & Acıbadem Maslak Hospital (İstanbul) & 5.099 & 360 & 5.459 \\
\hline & Bilgi Hospital (Antalya) & 11 & 4.911 & 4.922 \\
\hline & Dünya Göz Hospital Ataköy (İstanbul) & 1.873 & 1.936 & 3.809 \\
\hline & Ortadoğu 19 Mayıs Hospital (Ankara) & 26 & 3.699 & 3.725 \\
\hline & Medikal Park Hospital (istanbul) & 227 & 3.000 & 3.227 \\
\hline & Bayındır Hospital (Ankara) & 2.525 & 664 & 3.189 \\
\hline & Nisa Hospital (İstanbul) & 0 & 3.172 & 3.172 \\
\hline & Total & 23.119 & 28.855 & 51.974 \\
\hline & Percentage & $45 \%$ & $55 \%$ & $100 \%$ \\
\hline
\end{tabular}

Resource; Turkey International Patient Report 2015-2016

In Figures 6-7, it is seen that in 2015-2016, 10 branches receiving the highest number of international patients receiving health services in Turkey are seen. According to this, in 2015, international patients most used emergency medical services within the scope of tourist health. Emergency medicine services are mostly seen in medical tourism, eye diseases, gynecological diseases and childbirth. Emergency medicine services also became the health care branch that international patients most enjoyed in 2016. This indicates the scope of tourist health services. Emergency medicine services are mainly observed in eye diseases, gynecological diseases and birth which are included in medical tourism (Y1ldırım, 2017).

\subsection{SWOT ANALYSIS (for TURKEY)}

\subsubsection{Turkey's Strengths}

- Most of Turkey's private health institutions can compete with the west.

- The number of hospitals accredited with JCI is increasing day by day.

- Health tourism legislation regulation.

- Has rich thermal resources.

- Our country has centers of suitable climate, historical and touristic civilizations.

- It is a central location in the vicinity of our country that can address a population of 712 million people. 

country

- We have a potent business potential with young population and educability in our

- Provides health services through qualified human resources.

- Health care cost is low.

- EU countries' perspective on Turkey is changing positively and the process of entry into EU countries has begun.

- Technological and physical infrastructure, bed capacity and physician qualifications of universities and private hospitals are sufficient.

\subsubsection{Weaknesses}

- The number of health personnel (doctor, nurse, etc.) is less.

- Our policy on health tourism has just emerged.

- There is no institutional production in terms of health tourism.

- Possibility of employment of foreign doctor can be realized in the future period.

- Missed trained young trainees (can be trained)

- Foreign language education is poor and there are few language-speaking staff.

- Cooperation of state, NGO and sector representatives in health tourism is not fully achieved

- The promotion of our health tourism facilities abroad is insufficient.

\subsubsection{Opportunities}

- Basic principles of know-how transfer of knowledge and experience to my country

- Employment (health personnel and other personnel)

- Economic gain (foreign currency entry into the country)

- New investments (old holiday villagers, hospitals etc.)

- Social and political power generation abroad (Lobby Power)

- Strengthening the financial structure of the private health sector

- Foreign capital entry to our country

\subsubsection{Threats}

- Health professionals (especially doctors) shift to the growing private health sector (basic principle) increases)

- Increasing demand in private health institutions (the cost of health care services

- Communicable Disease can spread from abroad. (NDM-1 spread from India) Tbc, AIDS patients may come.

- The private health sector may refuse to provide services to its own people (GSS).

- Legal sanctions are not effective in malpractice (legal risks)

- Competition pressure from competitor countries 


\section{CONCLUSION}

We can expect an increase in productivity in these hospitals if the capacities of private sector health institutions are considered to be used. The public sector, which aims to exist with a small share in the sector, will feel its presence as supporting the sector with adequate physicians, hospitals and sub-structures. Policies should also be produced and marketing tactics should be developed in relation to the use of empty capacity as well, which is the factor that will increase the efficiency in health tourism.

When the causes of medical tourism patients' preference for hospitals are examined, it is stated that the hospital's reputation and price factors are the most influential factors, and the effectiveness of recommendation and promotion activities of the previous patients are in the upper order.

The quality of the health services offered in health tourism in Turkey is among the reasons that the costs are lower compared to other countries, the suitability of climatic conditions, and the multiplicity of holiday opportunities, short waiting periods, specialized hospitals and adequate technological equipment.

When we look at the distribution of medical tourism incomes and the number of patients coming in, Western European countries, which constitute a market of 185 million, have a significant market potential for Turkey.

Turkey manages a "medical tourism" process, which is based in Istanbul and has an important share in the "eye" field. It is important not to overlook the importance of health tourists who come for eye treatment, which has a significant growth potential due to the fact that eye treatments and operations are not paid by social security institutions and private health insurances.

\section{BIBLIOGRAPHY}

Aktürk, E.B. (2016). Perception regarding ethical rules implemented in the context of corporate governance: A study in banking sector (Doctoral Dissertation) Retrieved from The Council of higher Education Database (Accession No. 445669)

Association of Culture Toursim Offices. (2010). Thermals of Bursa Booklet.

Barca, M., Akdeve, E., Gedik, B. (2013). Strategic analysis of medical tourism in turkey and strategy recommendations. Journal of Business Research, 5(3), 64-92.

Carrera, P.M., Bridges, J.F.P. (2006). Globalization and healthcare: Understanding health and medical tourism. Expert Review of Pharmacoeconomics \& Outcomes Research, 6(4), 447-454.

Connell J. (2006). Medical Tourism; Sea, Sun, Sand and Surgery. Tourism Management, 27(4), 1093-100.

Dinçer, M.Z. et. al. (2016) Medical tourism in the developing countries: The assessment of the potential of Turkey compared to Thailand, Malaysia and India. Istanbul University, Journal of Social Sciences, (1), 34-60.

Gülen, K., Demirci, S. (2012). Türkiye'de Sağllk Turizmi Sektörü. İstanbul: İstanbul Chamber of Commerce Publishing.

Kaptanoğlu, R. (2017). An application on organisational commitment and emotional intelligence. IBANES, 3(3).

Kılıçarslan, M. (2017). Quality and inpatient satisfaction in health institutions x state hospital example. IBANES,3(3). 
Kördeve, M. (2016). An Overview of Health Tourism and Place of Health Tourism in Turkey. Journal of International Health Management and Strategies Research, 2(1), 53.

Republic of Turkey Ministry of Culture and Tourism \& Republic of Turkey Ministry of Health, General Directorate of Basic Health Services World Tourism Organization (2010). [Internet]. Coordinatorship of Health Torusim. Retrieved from: http://www.kultur.gov.tr/TR/belge/1_45771/mevzuat.html

Yıldırım, et. al. (2017). Turkey International Patient Report 2015-2016. 